\title{
A Review on: Phase '0' Clinical Trials or Exploratory Investigational New Drug
}

\author{
Klinik Faz'0'Testleri ya da Yeni İlaç Keşif Araştırmaları Üzerine Bir Derleme
}

\author{
Ashish A. GAWAI ${ }^{*}$, Faisal SHAIKH, Mangesh GADEKAR, Nitin DEOKAR, Shivanand KOLHE, K. R. BIYANI \\ Anuradha College of Pharmacy, Department of Pharmaceutical Chemistry, Maharashtra, India
}

\begin{abstract}
In a move to speed up the development of new medicines, the Food and Drug Administration announced in January 2006 the creation of the exploratory Investigational New Drug (IND), the so-called phase ' 0 ' clinical trials. This guidance is intended to clarify what preclinical and clinical approaches, as well as chemistry, manufacturing, and controls information, should be considered when planning exploratory studies in humans, including studies of closely related drugs or therapeutic biological products, under an IND application (21 CFR 312). Existing regulations allow a great deal of flexibility in the amount of data that needs to be submitted with an IND application, depending on the goals of the proposed investigation, the specific human testing proposed, and the expected risks. The agency believes that sponsors have not taken full advantage of that flexibility and often provide more supporting information in INDs than is required by regulations. This guidance is intended to clarify what manufacturing controls, preclinical testing, and clinical approaches can be considered when planning limited, early exploratory IND studies in humans.
\end{abstract}

Key words: IND, preclinical testing, clinical trials, phase 0

öz

Yeni ilaçların gelişimini hızlandırmak amacıyla Gıda ve İlaç İdaresi, Ocak 2006'da faz 'O' klinik testleri olarak adlandırılan keșif amaçlı Yeni Araştırılan İlaç (YAi) rehberinin oluşturulduğunu açıkladı. Kimya, üretim ve kontrol bilgilerinin yanı sıra klinik öncesi ve klinik yaklaşımların açıklığa kavuşturulması için tasarlanan bu rehber YAi uygulaması altında, yakından ilişkili ilaçlar veya terapötik biyolojik ürünler ile ilgili çalışmalar da dahil olmak üzere insanlarda keşif çalışmaları planlanırken göz önüne alınmalıdır (21 CFR 312). Mevcut düzenlemeler, önerilen araştırmanın amaçlarına, önerilen özgül insan testlerine ve beklenen risklere bağlı olarak YAỉ bașvurusu ile gönderilmesi gereken veri miktarında büyük bir esneklik sağlar. Ajans, sponsorların bu esneklikten tam olarak yararlanmadığına ve genellikle YAil'lerde düzenlemeler için gerekli olanlardan daha fazla destekleyici bilgi sağladığına inanmaktadır. Bu rehber, insanlarda sınırlı, erken keşif YAl çalışmalarını planlarken hangi imalat kontrollerinin, klinik öncesi testlerin ve klinik yaklaşımların düşünülebileceğini açıklığa kavuşturmayı amaçlamaktadır.

Anahtar kelimeler: YAl, klinik öncesi testler, klinik testler, faz 0

\section{INTRODUCTION}

The phase ' 0 ' clinical trials have tremendous scope in near future. It is also called exploratory Investigational New Drug (IND) or "micro dosing method". The purposes of this guidance the phase exploratory IND study is intended to describe a clinical trial that;

- Is conducted early in phase 1 ,

- Involves very limited human exposure, and

- Has no therapeutic or diagnostic intent (e.g., screening studies, micro-dose studies).

Such exploratory IND studies are conducted prior to the traditional dose escalation, safety, and tolerance studies that ordinarily initiate a clinical drug development program.,2 The duration of dosing in an exploratory IND study is expected to be limited (e.g., 7 days). This guidance applies to early phase 1 clinical study of IND and biological products that assess feasibility for further development of the drug or biological product. ${ }^{3.4}$ The major objectives of phase ' 0 ' trials is to interrogate and refine a target or biomarker assay for drug effect in human samples implementing procedures developed and validated in preclinical models. Data cleaned from a phase ' 0 ' trial are beneficial not only in prioritizing promising compounds but also in allowing the modification of phase 1 study design before initiation. Phase ' $O$ ' trials provide an opportunity to generate essential human pharmacokinetic and pharmacodynamics (PD) data earlier in the drug development process. ${ }^{5}$ With the help of phase ' 0 ' clinical trial only most promising compounds get into subsequent study, 
due to which sponsors reduces the excessive cost, time and human volunteers. ${ }^{6}$

\section{BACKGROUND}

In its March 2004 Critical Path Report, the Agency explained that to reduce the time and resources expended on candidate products that are unlikely to succeed, new tools are needed to distinguish earlier in the process those candidates that hold promise from those that do not.

\section{Traditional phase 1 approach}

Typically, during pharmaceutical development, large numbers of molecules are generated with the goal of identifying the most promising candidates for further development. These molecules are generally structurally related, but can differ in important ways. Promising candidates are often selected using in vitro testing models that examine binding to receptors, effects on enzyme activities, toxic effects, or other in vitro pharmacological parameters. ${ }^{7}$

These tests usually require only small amounts of the drug. The candidates that are not rejected during these early tests are prepared in greater quantities for in vivo animal testing for efficacy and safety. Commonly, a single candidate is selected for an IND application and introduction into human subjects, initially healthy volunteers in most cases. If this phase 1 get passed then drug goes towards phase 2 and then phase 3 but drug get eliminated then again take its analogue or other drug and again repeat this procedures. Upto 250 drug candidates involved in preclinical study from that only 1-2 drug molecules get into market. Upto $67 \%$ fail in phase $1,45 \%$ in phase 2 and $8 \%$ in phase 3 this percentage are on the basis of those drugs get passed from animal models and evaluated in the clinical phases [United State Food and Drug Administration (FDA), Center for Drug Evaluation and Research, 2006]. ${ }^{8}$

\section{Exploratory Investigational New Drug approach}

Exploratory IND studies can help to identify important essential promising drugs for further development and if not can eliminate such type of drug candidate. As a result, exploratory IND studies may help to reduce the number of human subjects and resources, including the amount of candidate product and need to identify important promising candidate. The clinical trials studies involve dosing a very small and limited number of subjects (patients) with a very small and limited range of doses for a specific period of time. ${ }^{9}$

\section{Need of phase ' $O$ ' clinical trials}

Anthony ${ }^{10}$, and Kummar and Rubinstein ${ }^{11}$, in this research paper discussed the need and use of phase ' $O$ ' clinical trials as fallows.

- For getting pharmacokinetics (PK) and PD data early in phase 1 , this would be helpful in further assessment or for evaluation of compound.

- Time period can be reduced by examining only capable drug candidate for further study.
- Costs of New Drug Development process get reduced, by studying only most promising compound in further study.

- \% drug into market get increased, because unwanted compounds get eliminated in the phase ' 0 ' clinical trials.

\section{Criteria for phase ' $O$ ' clinical trials}

Anthony ${ }^{10}$, Kummar and Rubinstein ${ }^{11}$, and James ${ }^{12}$, have explained the criteria for phase ' $O$ ' clinical trials.

- Before phase 1 study,

- Fill the exploratory IND application,

- Volunteers are healthy human or patient,

- Less than 15 volunteers,

- Duration 7 days,

- Dosing $1 / 100^{\text {th }}$ or $100 \mu g$ or 30 nanomole,

- Only one dosing cycle for study,

- In anti-cancer IND pre and post tumor biopsies done if required.

\section{Micro-dosing approach in phase 'O' clinical trials}

Micro-dosing approach is adopted for evaluating PD (Mode of Action) and PK (volume of distribution, binding and clearance) in the human being for predicting or selecting the most promising drug candidate or its analogue for further study. Due to it unnecessary drug candidate separated from phase 1 or from further study and investigator save unnecessary wastage of money, time and risk concerned with human volunteers. By using only a very tiny amount of active substance, one can establish the more appropriate pharmacological dose and with this estimate the first dose for phase 1 clinical trials study. With addition, micro-dosing can select the better animal species and model for toxicological studies mainly for long term studies from micro-dose metabolite profiling data. Ultrasensitive methods are required for evaluation of very small amount of drug substance in the human body. Concentration $10^{-12}$ to $10^{-15}$ gm should be the range of method which should be employed for evaluation of micro-dose. There are two methods which having such abilities of evaluation of micro-dose. These techniques rely on radioisotopes incorporation.12,13

Two methods used and this technique was explained by Hung ${ }^{9}$ and Rani and Naidu ${ }^{14}$.

Accelerator Mass Spectrometry: This technique is used for evaluation of pharmacokinetic data mainly. In this technique radioisotope $\mathrm{C}^{14}$ is used for the evaluation of drug or microdose. The half-life of this radioisotope is 5740 years.

Positron Emission Tomography: This is mainly used for evaluation of $P D$ data. For evaluation of $P D$ data $C^{11}$ radioisotope is used which having 20 min half-life.

Phase ' $O$ ' trials in oncology study

Kummar and Rubinstein", had conducted the first phase ' 0 ' clinical trial for cancer study with sub therapeutic and therapeutic drug candidate under the IND guidance of the FDA. It was first 
time in human (First in Human) study of the poly(adenosine diphosphate-ribose)polymerase (PARP) inhibitor code name given (ABT-888) in volunteers with advanced malignant cancer. Promising candidate ABT-888 was administered as a single oral dose of 10,25 or $50 \mathrm{mg}$ to identity and determines the dosage regimen with duration of time for which drug candidate (ABT888) inhibits PARP activity in tumour samples and peripheral blood cells as well as estimate candidate (ABT-888) PK profile. Blood samples and tumour biopsies were obtained before and after drug administration for evaluation of PARP activity and PK. A novel statistical approach was developed and utilized to study PD modulation as the primary end point for trials of limited sample size. $5,7,11$

Thirteen patients with advanced malignancies received the study drug; nine patients undergone paired tumour biopsies. ABT-888 demonstrated good oral bioavailability and was well tolerated. Statistically significant inhibition result was observed in tumour biopsies and peripheral blood cells at their respective dose level particularly at 25 and $50 \mathrm{mg}$ dose levels. They obtained very important biochemical and pharmacokinetic data within 5 months of study that have guided the design of phase 1 trials of candidate ABT-888 in combination with DNA damaging agents. In addition to accelerating the development of $A B T-888$, the immediate finding of this trial explained the feasibility of conducting phase ' $O$ ' trials as part of an alternative program for early drug development in cancer study. ${ }^{15}$

Role of FDA in phase ' $O$ ' trials

Lorusso $^{16}$, Vijayraghavan and Kumar ${ }^{17}$, and Singh ${ }^{18}$, were explained the role of phase ' $O$ ' trials in FDA.

According to the FDA a phase ' $O$ ' is designed to carry out before in phase 1, it has very limited human exposure receiving only sub-therapeutic dose and this means the volunteer produces a response (Pharmacological Action) than the toxic effect with less risk compared to conventional clinical trials in phase 1 in which administration continues if clinical benefit which means even phase ' $O$ ' trials don't have any therapeutic intention. With the ultrasensitive accelerator mass spectrometry (AMS) it was possible to carry out clinical trials in human using small dose to obtained pharmacokinetic data. ${ }^{16,17,18}$

\section{Limitation for micro-dosing techniques}

Rani and Naidu ${ }^{14}$, Hermann ${ }^{19}$, and Bertino et al. ${ }^{20}$, had discussed the limitation for micro dosing techniques as fallows.

- It is new technique hence database is small,

- Micro-dose is sophisticated for the evaluation,

- Positron emission tomography (PET) has short half-life i.e. 20 min so on time testing is required,

- Both assay i.e. PET and AMS have limited specificity so test results are also having some time trouble due to this limited specificity,

- Micro-dose may not predict the behaviour of therapeutic or clinical dose.

Difference in between phase ' $O$ ' and phase ' $i$ ' in oncology study James $^{12}$, Anthony ${ }^{10}$, Murgo et al. ${ }^{21}$, Takimoto ${ }^{22}$ and Kummar et al. ${ }^{23}$ have explained the differences of phase trials described in Table 1 for oncology study.

\section{Goals of phase ' $O$ ' clinical trials}

Anthony ${ }^{10}$, Lorusso ${ }^{16}$, and Lappin and Garner ${ }^{24}$ had discussed the goals of phase ' $O$ ' clinical trials as fallows.

- Define the Mode of Action (MOA) in non-clinical models achieved in human,

\section{Table 1. Difference in between phase ' $O$ ' and phase 1 clinical trials}

\begin{tabular}{|c|c|c|}
\hline Phase '0' & Variable & Phase 1 \\
\hline Less required & Preclinical toxicological study & Full IND required \\
\hline $\begin{array}{l}\text { Target/biomarker analytical assays validated in } \\
\text { preclinical models }\end{array}$ & $\begin{array}{l}\text { Pre-clinical target/biomarker validation } \\
\text { studies }\end{array}$ & Not consistently performed \\
\hline Establish a dose-range & Primary objective & Establish dose limiting toxicities \\
\hline Limited dosing (e.g., 1-7 days) one cycle only & Limited dosing (e.g., 1-7 days) one cycle only & $\begin{array}{l}\text { Repetitive; multiple cycles until disease } \\
\text { progression or unacceptable toxicity }\end{array}$ \\
\hline None & Evaluation for therapeutic benefit & Tumor response routinely evaluated \\
\hline Required (pre- and post) to evaluate drug effect & Tumor biopsies & Almost always optional \\
\hline $\begin{array}{l}\text { Integrated into the trial to establish MOA and } \\
\text { target/biomarker analytical assay validation in } \\
\text { subject tissue samples }\end{array}$ & $\mathrm{PD} /$ target effect assays & $\begin{array}{l}\text { Not consistently performed; commonly use } \\
\text { assay methods that are not validated or } \\
\text { standardized }\end{array}$ \\
\hline Performed in "real-time" & PK/PD analysis & $\begin{array}{l}\text { Samples usually batched and analyzed at a } \\
\text { later time point, generally after completion } \\
\text { of the trial }\end{array}$ \\
\hline
\end{tabular}

IND: Investigational New Drug, MOA: Mode of Action, PD: Pharmacodynamics, SOP: Standard operating procedure, PK: Pharmacokinetics 
- Define a biomarker assay by using human tumor tissue,

- Develop the novel imaging probe for evaluation of binding characteristics, bio-distribution and target effect,

- Evaluate PK and PD of drug and its analogue for selecting most promising candidate,

- Provide PK and PD data for further study i.e. phase 1 and further.

\section{Advantages}

Phase ' $O$ ' clinical trials have several advantages before starting other phases of clinical trials. Vijayraghavan and $\mathrm{Kumar}^{17}$ and Lappin and Garner ${ }^{24}$ explained these advances as fallows.

- The time periods get reduced with the help of earlier testing of pharmacological action of new test candidate.

- It helps to select desirable promising targeting compounds for further extensive study before the conventional phase 1 trials.

- They help in overall acceleration in the process of drug development by focusing only the promising compounds.

- They avoid unnecessary exposure of the participants in the trial to the not so promising compounds.

- They possess less risk of human toxicity with low dose of the test candidate and less time duration for exposure. Moreover, a very limited number of subjects are involved. Also, such trials mostly involve a single dose administration as compared to a dose escalation study in the traditional phase 1 trials, there by further minimizing the risk.

- Pre-clinical safe site compared to conventional phase 1 clinical trials.

- Less number of animals is used.

- Overall time of drug development is reduced.

- This methodology helps in early selection of the smarter and more promising lead molecules hence, the more effective drugs reach to the market earlier.

- Small quantity of the test drug is required.

- All test drugs prepared according to principles and procedure of Good Laboratory Practices (GLP) as well as Good Manufacturing Practices for conventional phase 1 clinical trials.

- Any route of administration is possible.

- The drug canbe studied in sensitive patient like renal impairment, women in their reproductive age, cancer patients etc.

- This approach can help in studying the test drug for its modulator effects on the targets in a tumour.

- This approach is useful in the discovery of endogenous biomarkers for evaluating the quantitative effects of the test drug.

- The not so promising molecules can be eliminated earlier, thereby saving costs.

- They are helpful in obtaining the nearby therapeutic dose so determining the first dose for the further phase 1 study.
- The PK data can be obtained in only near about six month as compared to nearly 18 months in case of conventional phase 1 studies.

- They may help in selecting the best animal species for the long term toxicological studies based on the inference drawn from the micro-dose metabolite profiling data.

\section{Disadvantages}

Vijayraghavan and Kumar ${ }^{17}$ and Eliopoulos et al. ${ }^{25}$, had explained disadvantages of clinical trials phase ' 0 ' as given below.

- There is lack of any therapeutic as well as diagnostic intention.

- It may be difficult to motivate the volunteers to become a part of the trial because no therapeutic intent.

- Participation in the phase ' 0 ' trials may reduce the overall load of the subjects who become a part of the conventional phase 1 trials having therapeutic intention.

- Very few validated biomarkers are available for predicting the anti-cancer activity.

- There is requirement of ultra-sensitive and high tech equipment's like AMS and PET which are scarcely available.

- Since the technique of micro-dosing is still in its infancy, before applying this methodology precaution needs to be exercised to the drugs showing complex/non-linear kinetics.

- Since certain drugs dissolve readily at low dose but exhibit limited solubility at higher doses, it may be difficult to predict the absorption characteristics at the micro-dose levels.

- Phase 1 still needs to be done hence phase '0' unnecessarily prolongs the process and inflates the expenditure.

\section{Content of exploratory investigational new drug submissions}

FDA in 2006 explained and discussed the different documents for the submission for clinical trials phase ' 0 '. Some of the important documents list as fallows. ${ }^{26,27}$

Clinical information;

- Introductory statement and general investigational plan,

- Types of studies,

Chemistry, manufacturing, and controls information;

- General information for the candidate product,

- Analytical characterization of candidate product,

Safety program designs;

- Clinical studies of PK or imaging,

- Pharmacological proper dosing needed for clinical trials,

- Clinical studies of MOAs related to efficacy,

- GLP compliance.

Volunteers recruitment in phase ' $O$ ' clinical trials

Volunteer's recruitment is important part in all phases of clinical trials. Anthony ${ }^{10}$, Fabio et al. ${ }^{28}$ and Lexchin ${ }^{29}$, had explained the recruitment of volunteers in phase ' 0 ' clinical trials. 
Potential barriers to patient enrollment in phase 'O' clinical trials because:

- No therapeutic intent or chance of benefit,

- Tissue biopsies before and after treatment,

- Other clinical trials or therapies deletion and delay study.

But plus points are:

- Low risk,

- Avoid biopsies if possible,

- Washout period is shorter.

\section{CONCLUSION}

The FDA has undertaken and initiated various approaches to reduce time, money and other factors in early drug development on such products that may be successful in near future. The detail guidance issued by FDA entitled "Exploratory IND Studies" described exploratory approaches exist in USA that are consistent with regulatory requirements currently but that will enable sponsors to move ahead more efficiently for successful product development of initial promising future candidate with needed human subject protections.

The preclinical testing programs for phase ' 0 ' or exploratory IND studies may be less extensive compare to conventional IND studies. This is because for the approaches described under this guidance, which maintain the administration of doses of promising candidate with minimum risk to subject compare to conventional phase 1 clinical trials. In near future the micro-dose study will place a remarkable event in drug development for all first in human studies in clinical trials. It is ethical to expose human subjects unnecessarily to a pharmacological dose of potential drug that has poor PK/PD properties, whose development is terminated as a result, when the same information could have been obtained in a microdose study. The micro-dose approach used in the exploratory IND trial will make a contribution to smarter drug development by enabling early human data to be obtained. Drug selection as a result will become more human based and therefore more predictive.

Phase ' $O$ ' clinical trials are advantageous for the investigation sponsor, volunteers and public. Due to phase ' 0 ' clinical trials increased the chances of investigational drug into the market and reduce the unnecessary time, cost and volunteers in new drug development process by eliminating the unnecessary drug candidate prior to the phase 1.

Conflict of Interest: No conflict of interest was declared by the authors.

\section{REFERENCES}

1. Garner RC, Lappin G. The phase 0 microdosing concept. Br J Clin Pharmacol. 2006;61:367-370.

2. Gutierrez M, Collyar D. Patient perspectives on phase 0 clinical trials. Clin Cancer Res. 2008;14:3689-3691.
3. Seth SD, Kumar NK. Human micro-dosing study. Indian J Med Res. 2009;130:202-204.

4. DiMasi JA. Risk in new drug development: approval success rate for investigational drugs. Clin Pharmacol Ther. 2010;87:272-277.

5. Lappin G, Kuhnz W, Jochemsen R. Use of microdosing to predict pharmacokinetics at the therapeutic dose: Experience with 5 drugs. Clin Pharmacol Ther. 2006;80:203-215.

6. Wood AJ. A proposal for radical changes in the drug development process. N Engl J Med. 2006;355:618-23.

7. Kinders R, Parchment RE. Phase 0 clinical trials in cancer drug development: From FDA guidance to clinical practice. Mol Interv 2007;7:325-334.

8. Food and Drug Administration, Guidance For Industry, Investigators and Reviewers Exploratory IND Study, CDER, U.S. Department of Health and Human Services, Washington DC, USA 1-12, 2006.

9. Hung JC. The exploratory IND (Phase '0') concept. Ann Nucl Med Sci. 2009;22:93-100.

10. Anthony JM. Phase ' $O$ ' trials- role in radiation mitigation agent development. USFDA 2010;25:1-27.

11. Kummar S, Rubinstein L. Phase ' $O$ ' clinical trials: conceptions and misconceptions. The Cancer J. 2008;14:133-137.

12. James HD. Phase ' $O$ ' clinical trials in cancer drug development: From concept to practice. National Cancer Institute. 2015;1:26.

13. Boyd RA, Lalonde RL. Non-traditional approaches to First-in-human studies to increase efficiency of drug development: Will microdose studies make a significant impact? Clin Pharmacol Ther. 2007;81:24-25.

14. Rani PU, Naidu MVR. Phase 'O' micro-dosing strategy in clinical trials. Ind J Pharmaco. 2008;6:240-242.

15. Kummar S, Kinders R. Phase ' $O$ ' Clinical trials of the poly (ADP Ribose) polymerase inhibitor ABT 888 in patients with advanced malignancies. $J$ Clin Oncology 2009;27:2705-2711.

16. Lorusso PM. Phase ' 0 ' Clinical Trials: An answer to drug development stagnation. J Oncology. 2009;27:2586-2588.

17. Vijayraghavan R, Kumar GR. Impact of phase ' 0 ' trials (micro-dosing) in clinical trial research. Int J Applied Bio Pharm Tech. 2010;1:486-491.

18. Singh S. Clinical trial new horizon India. CDSCO 2012;1-32.

19. Hermann AM. Microdosing in Translational medicine: Pros and Cons. Advances reports. Cambridge Health Associates. 2006;5:5-9.

20. Bertino JS Jr, Greenberg HE, Reed MD. Position statement on the use of microdosing in the drug development process. J Clin Pharmacol. 2007; 47:418-422.

21. Murgo AJ, Kummar S, Rubinstein L. Designing phase 0 cancer clinical trials. Clin Cancer Res. 2008;14:3675-3682.

22. Takimoto $\mathrm{CH}$. Phase 0 clinical trials in oncology: A paradigm shift for early drug development? Cancer Chemother Pharmacol. 2009;63:703-709.

23. Kummar S, James HD, Joseph ET. Phase ' $O$ ' clinical trials: recommendations from the task force on methodology for the development of innovative cancer therapies. Eur J Cancer. 2009;45:741746.

24. Lappin G, Garner RC. Big physics, small doses: The use of AMS and PET in human microdosing of development drugs. Nat Rev Drug Discov. 2003;2:233-240. 
25. Eliopoulos H, Giranda V, Carr R. Phase 0 trials: An industry perspective. Clin Cancer Res. 2008;14:3683-3688.

26. "Innovation or Stagnation, Challenge and Opportunity on the critical path to New Medical Products" U.S. Department of Health and Human Services, Food and Drug Administration, March 2004.

27. Marchetti S, Schellens JHM. The impact of FDA and EMEA guidelines on drug development in relation to phase 0 trials. Brit $\mathrm{J}$ Cancer. 2007; $97: 577-581$.

28. Fabio AT, Anthony JS, Ernst RB. Trends in the globalization of clinical trials. Nat Rev Drug Discov. 2008;7:12-14.

29. Lexchin JR. Implications of pharmaceutical industry funding on clinical research. Ann Pharmacother. 2005;39:194-197. 